\title{
Gender relations in indigenous Yorùbá culture: Questioning feminism action and advocacy
}

\section{Luqman Opẹeyẹmí Muraina ${ }^{1}$ and Abdulkareem J. Ajímátanraẹjẹ ${ }^{2}$}

Department of Sociology, University of Cape Town (UCT), South Africa, Department of Sociology \& University of Lagos (UNILAG), Nigeria ${ }^{1}$ and Olabisi Onabanjo University (OOU), Nigeria $^{2}$.

\section{Corresponding author name - Luqman Muraina}

ORCID iD: 0000-0002-2655-148X

Email-murainaluqman@gmail.com

LinkedIn: Muraina Luqman - https://www.linkedin.com/in/muraina-luqman-4619a3153/

\begin{abstract}
Western feminism has diffused to many other cultures, who have imbibed without proper reflection. This is similar for the Yorùbá people of South-Western Nigeria. Yorùbá culture is gender-neutral and gender-silent; women are seen as complementary and not subordinate to men. Hence, (Oyěwùmí 1997), caution must be raised on the continual adoption of mainstream Western feminist philosophy in Yorùbá culture. Consequently, an argument was submitted for a different approach to doing feminism in Yorùbá culture. In essence, colonial imposition of gender binary in Yorùbá society; roles and gender status of women in traditional Yorùbá culture; women anti-colonial and feminist activities were discussed. The decolonization of Africa and the Yorùbá education system to include a properly historicized indigenous knowledge was recommended. Current feminist movements must also develop a 'shared text of blackness'. The duo should align and improve the worth of women based on the indispensability and esteemed status offered to women in pre-colonial Yorùbá society.
\end{abstract}

Keywords: Black feminism; colonialism; gender; indigenous society; pre-colonial; Yorùbá culture.

This is a preprint/AOM that has been submitted to an indexed journal for peer-review publication. 


\section{Introduction}

Gender discourse is one marred with many arguments and differing scholarship thoughts. This study intends not to contribute to this argument but to utilize popular gender discourse to contribute to Black feminism ${ }^{1}$. Generally, two categories are popular in explaining the gender identity of a human body: the sexual and gender explanations. The former interprets the biological facts of being a male or female, and gender refers to the social consequences of being either of the two sexes. However, the Yorùbá society that is the crux of this study holds heteronormative gender categories tightly, and it is mainly a bi-sexual society. Remember, Nigeria, where Yorùbás are predominantly located, is still male and female divided and resists (legally and morally) all forms of new gender identifications. Meanwhile, (Oyěwùmí 1997) noted that sex and gender are inextricably bonded, i.e., the way scholarship has read meanings to human sexes in any particular time and society is also a function of social relations. Martin (1991) shares similar ideas on how science scientifically hierarchized sexes based on the prevalent social ties during those 'scientific' periods.

Henslin (2010) described gender stratification as a master status or a universal culture, thus, affirming the pervasiveness of gender stratifications and/or inequalities in many societies. In explaining gender stratifications, the nature/biological and nurture/social philosophies are widespread. These are referred to as biological determinism and social constructionism in Oyěwùmí (1997). Biological determinism explains that the male gender was naturally created and developed to control society (Martin 1991). The other argument is that society produces patriarchalism and, therefore, changeable - social constructionism.

Whether biological determinism or social constructionism, today's Yorùbá society is patriarchal and favours masculinity over femininity (Akanle, Adesina, and Nwaobiala 2018). This has paved the way for multidimensional and intersectional feminist activities. As such, the study aims to a discourse on gender relations in the Yorùbá culture concerning how they are framed in present times and feminist advocacy in that part of the world. This would be achieved by visiting indigenous Yorùbá culture vis-à-vis its collusion with colonialism and foreign cultures.

\section{Methodology}

\footnotetext{
${ }^{1}$ Black feminism can be translated in the Yoruba cosmology as İṣẹttọ́fábo (Ọ̀pẹfèyítìmí 2014).
} 
The methodology of research work is intended to guide on the approach, methods, strategies and techniques of gathering data and how it shall be utilized amidst ethics and limitations. Meanwhile, 'methodology' is not used in the sense of quantitative surveys or qualitative ethnographic studies. Methodology herein only refers to the framework that shall be adopted in presenting our argument on how Yorùbá women are an indispensable force in the functioning and workability in traditional pre-colonial Yorùbá society and their present status upon continuing colonial interactions.

In that light, this study recognizes the social theorization of Fraser (1998) on 'Perspectival Duality'. The work acknowledges female subjugation and patriarchalism of many societies. It seeks to research to change the status quo on the inferiority status placed on the female sex. Perspectival duality discusses social justice laced between redistribution and recognition (Fraser 1998). Going forward, the sine-qua-non status of Yorùbá women and the notable roles they performed will be discussed. In doing this, Yorùbá land contact with British colonialism will be exposed. Consequently, the importance of perspectival duality in this study via feminist activities of redistributing rights and recognizing women would be asserted.

The provocative and critical work of Oyěwùmí (1997) is a foundation for the analysis in this article. Oyěwùmí and Mangcu (2016) recognize the indispensability attitude with which studies in Africa have imbibed western ontologies and epistemologies. She argued that when Africa nativists are not directly invoking Eurocentered philosophies on gender identities, they relate Africa's experience with the West without proper 'indigenous' historicization of the gender relations in Africa. The work shares similar characteristics with outlier decolonization ideas presented in Lugones (2008) and Wane (2011). Hence, the study is met with scholarly attacks (King 1998; Adésuyì 2014; Manicom 2001) and support (Ficek 2011; Creevey 2000). Decolonization asks us to question and rethink hegemonic Western and Eurocentric epistemologies and conduct critical narration of indigenous peoples stories on African existence (Kaya and Seleti 2014). The 'Invention of Woman, Making an African Sense of Western Gender Discourses' presents an opportunity to decolonize Western feminism and take actions to deconstruct and reconstruct colonial knowledge, properly historicize and critique existing frames (Le Grange 2016).

The Yorùbá people of Nigeria occupy most of the Southern part of Nigeria, which they share with the Igbo people and other minority groups. Furthermore, they control the totality of one 
of the six geopolitical zones in Nigeria - South-West, encompassing Èkìtì, Lagos, Ògùn, Ondó, Òșun, and Òyọ́. They are also the dominant ethnicity in Kwara state. References would also be made to the Western region, the colonial geographical location of the Yorùbá people.

\section{Gender in Yorùbá Culture and Interaction with Colonialism}

Today, the Yorùbá culture is patriarchal, and societal divisions have been created across gender lines (Akanle, Adesina, and Nwaobiala 2018; Aderinto 2001; Pogoson 2012). Patriarchy allows men privileges such as employment, higher education attainment, and societal opportunities. In Yorùbá culture, men are seen to be capable of catering for themselves. From their youthful age, men are allowed for night outings, long-distance travelling, late marriage, distance away from their family of orientation for education, training, bread search, and also perform lesser household chores. They are less reprimanded relatively to women regarding home offences, committing adultery, etc. Unfortunately, women are not allowed these privileges, although this varies across specific native cultures. The unequal status allowed and owned by women has influenced mainstream feminist activities. Feminism goals includes changing women's narratives in the face of a society that does not give nor allow them a voice of their own. Meanwhile, before commenting on the actions and inactions of the new waves of feminism practised in Yorùbá land, it is essential to identify the roots of female oppression and subjugation in Yorùbá culture vis-à-vis cultural diffusion and assimilation.

The new wave of Black feminism and Pan-African feminism has shown and asserted that Africa interaction with Europe caused doom to its gender orientations (Oyěwùmí 2016; Johnson 1982; Akanle, Adesina, and Nwaobiala 2018; Amadiume 1987; Wane 2011). Johnson (1982) speaking on women activities in colonial South-Western Nigeria, concluded that colonialism altered their social positions and affected their economic \& political power and roles. Henceforth, inference can be made that gender disparity was not the norm in Yorùbá precolonial society. Many accounts like Johnson asserted that gender relations were not the crudest and fundamental dictator in social relations. Gender played secondary roles in social relations in Yorùbá culture.

Gender hierarchy importation is pervasive in Africa. Women usually have their places and do not contest any role with the opposite male gender. This includes political, economic, religious, family, health, etc., affairs (Wane 2011). Specifically, in Yorùbá society, women have high places of honour and status. Their disagreement with a decision or policy is tantamount to the 
annulation of the policy. Johnson also raised remarkable expressions specifically on the outstanding actions of Southwestern women to question the problem of gender binary imposition:

One area where women's movements were particularly important in anti-colonial activity was southwestern Nigeria. Here women possessed a long and rich history of collective organization through which they articulated and protected their interests from precolonial times onward. (Johnson 1982, 137)

Subsequently, it is essential to ask how Western colonialism created gender hierarchies, which specifically placed men above women and the popularity of sex-typing. This activity must include comparing women status in pre-colonial and colonial periods. According to Oyěwùmí (1997), colonizers adopted tools such as education, land ownership, cocoa production, religion (Christianity) and leadership, 'customary' courts, employment, etc., to berate and wield power from women. Female voting limitations and tax payment were also narrated (Johnson 1982; Amadiume 1987; Adetunji 2013).

Oyěwùmí (1997), Ajala (1977), and Imam (2012) narrated the inextricability of western education and missionary activities. Oyewumi furthered on how the duo was used to create an explicit gender binary. For example, men were explicitly targeted in the effort of missionaries to develop persons who would establish and spread the gospels independently and 'civilize' other societies. They were seen as capable and competent to become evangelists, pastors, clerks, interpreters, assistant engineers, etc. Thus, separate and distinct education was offered to the masculine and feminine bodies. While men received missionary education (later critiqued by the colonial government (Imam 2012)), special classes were given to women in embroidery and sewing. Thus, the kind of education offered to women is targeted to make them become 'responsible wives' to the pastors and teachers men. Remember, missionary wives performed these roles, so it is not surprising if such a system is replicated in colonial societies. More so, education differentials based on gender was so pervasive that educated females were short in supply for males to marry (Oyěwùmí 1997, 134).

Moreover, colonial settlers opinion that Africa lacks civilization and modern culture (Fanon 1961; Rodney 1972; Kuykendall 2016) would make them wilfully blind to the fact that Yorùbá society was gender-neutral, albeit this is against the norm in Europe. Thus, missionary education marked the genesis of creating gender binary and was not heavily observed nor 
criticized by natives. This is because saving souls for life after death was the manifest purpose of missionary education. Influential Nigerian missionaries like Chief Ajayi Crowther encouraged the nobles, elders, and chiefs to enroll their wards. This is in addition to rescued slaves that returned from Sierra Leone who were easily enrolled in missionary schools, churches, and houses (Ajala 1977). In all of these, sexism played a latent role and was not inherent. The strict boarding school system aiding missionaries civilizing mission provided for the overall control and supervision of native students' daily life and isolation from their 'pagan past' (Ajala 1977). Consequently, Eurocentric norms promoted in missionaries premises would be inaccessible to the larger society.

Meanwhile, as events unravel, women continue to fill the brunt of gender hierarchy across several social organizations. Land in Yorùbá society has always been a free commodity to be kept in trust by family heads (lineage based) and traditional rulers (community-based). It would be given to entitled persons in need of land and extended to strangers where appropriate (Mamdani 1996). However, this system did not allow women to be double entitled. In an instance of exogamous marriage, women may be entitled to two lands, both at their families of orientation and procreation. However, access to land for women was majorly by their lineage/community of birth and not of marriage (Oyěwùmí 1997). Subsequently, colonialism created systems where land was commercialized; and the public status of land became private properties (Rodney 1972; Mamdani 1996). The system adopted was through ordinance, crown grants of land, etc. These mechanisms wielded free access to lands from women because the colonizers regarded only males as complete individuals.

Also, as would later be exposed in this paper, women had little access to cash since they were grossly uneducated, and those who were educated were legally not employed or promoted like the male folks (Johnson 1982). Furthermore, colonialists' unique recognition of cocoa as a valued commodity in Western Nigeria further made land a valuable commodity. Cocoa commercialization created a monopolistic market for men, as women were seen as unfit to grow cocoa. The female gender was also not supported by the government (finance, seedlings, lands, etc.) to grow cocoa. The empowered male family heads and traditional rulers also became unwilling to pass cash-crop lands through their daughters in the next generation except for their sons only. 
The colonizers created the power that allowed male-only lineage heads and traditional rulers to enhance female subjectivity. Traditionally, the Yorùbá society was noted for its monarchical democracy, characterized by checks and balances. Although monarchical, the Obas - Kings do not hold total governance control as many institutions would easily check the king's excesses. Women associations were also notable amongst these groups. Moreover, in every grouping in Yorùbá custom and tradition, there is always a place of women, be it governance, religion, industry, law, health, social (ẹgbẹ - age groups) etc. Yorùbá culture recognized special female offices like the İyálóde - Woman king subject, İyá Àbíyè - female midwife, Yèyé Ọṣun - water goddess, İyá Lọjà - female market leader, Erelú - female overall leader, İyámojẹ - female masqurades leader, İyá mogbà - Sango female cultist. These positions are revered by the totality of the society (Makinde 2004); moreover, some of them hold extraordinary supernatural power (Adetunji 2013). They could use them to seek benefits, including seeking favours and punishing deviators (Makinde 2004). Today, these offices still exist for women, unfortunately holding ceremonial status only.

Colonial administration created indirect rule, or what Mamdani (1996) referred to as decentralized despotism as a political system that assisted the colonial enterprise, which only recognized men as native rulers. For easy and selfish control of districts, British settler colonialists appointed men who would direct and control the affairs of the population under a system known as native authority. While indirect rule might not have dismissed the existing traditional authorities; it made irrelevant the institutionalized mechanisms that acted as checks against the usual male rulers. It also refused to recognize women as capable of participating in this system. Thus, traditional male chiefs make laws, administer, and punish offenders.

Mamdani (2001) related that pre-colonial Africa did not have a single 'customary'2 court as political administration and governance is decentralized across family, district, and township levels. To further aggravate the situation, matters initially referred to as communal/familial became matters of 'customary courts', where only the male chiefs were represented. Matters such as family disputes, land ownership, divorce, etc., became a council of male chiefs affair in a modernized static 'customary courts'. Mamdani (2001) and Oyěwùmí (1997) also reported the despotic, tyrannical behaviours of the male chiefs.

\footnotetext{
2 Authors have noted that there is nothing customary about the colonial 'customary' Native Authority (Mamdani 1996; Oyěwùmí 1997). The representatives of customary administrations were appointed by settlers' to serve colonial enterprise, i.e., direct taxation, price control, rule \& order.
} 
It is also important to relate how the offshoots of education, i.e. writing and translation, created hierarchical gender categories in religion (Christianity and Africa indigenous religion). In language and writing, the English language gender orientations, i.e. him/her, he/she, etc. Meanwhile, Yorùbá language and society do not specify gender differences in speaking and writing but rather chronological age differences (Oyěwùmí 1997). Yorùbá acknowledges agehierarchy against gender hierarchy; hence, roles, responsibilities, expectations, etc., were premised on peoples' age and not their gender. The young population is socialized to be respectful of the adults. This is inherent in transiting from ooooo to eẹeẹe when socializing or when an individual need to answer their name. The former is used for people of lesser age or colleagues, and the latter for persons older than you. There are many ways in which the Yorùbá language created age honorifics, a reason foreign cultures refer to the southwestern people of Nigeria as overly respectful. Social control is built on age and social respect systems. This control is so influential that you shall not disrespect someone who is a day older than you. You shall be rebuked that - Tó bá jẹ ojọ́ kan ló fi jù ẹ lọ, oò lè ri rà lọjà, - if they are only older than you with a day, it is unselleable in the market. Meanwhile, another author cautioned that a nongendered society can not be totally identified by the language structure of that society, as language does not perfectly reflect social organizations, inequalities, and stratifications. (Manicom 2001). While language alone would not provide evidence of a gender-neutral and gender-silent Yorùbá society, it constitutes an additional argument by Black feminist writers.

Translating English to Yorùbá language and vice versa was also challenging as both are structurally different. In comparison, English language pronouns and adjectives have gender implications against the Yorùbá languaging system. This created a clash between a gendersilent Yorùbá language against a hegemonic English; it is needless to say what language suffers when translating or interpreting both languages. Oyěwùmí (1997) narrated that the process of creating a Yorùbá Bible, referred to as Yorubanizing Christianity, unfortunately, influenced the 'Christianization of the Yorùbá religion'. For example, the three pillars of Africa religion Olódùmarè, Òrìsà and Aláké, i.e. God, gods, and ancestors had representations of both genders. There are male gods, i.e. Șàngó, Ògún, etc., and female gods - Ọș̣un, Òrìsàlá etc. Also, Șàngó is not superior to Ộṣun as gods are invoked on a case-specific situational basis. Unfortunately, Yorubanizing Christianity made Olódùmarè - Father in Heaven/God painted as a Man; henceforth, male gods became powerful than females. Also, ancestors become forefathers, as if the females do not die and are not venerated by their families. In pronoun usage, God, gods 
and ancestors become he. Meanwhile, Yorùbá language would refer individual spirits with plural affirmatives, further affirming the social respect in Yorùbá society.

The Yorùbá society used to be gender-neutral and gender-fluid (Oyěwùmí 1997; Oyewumi 2002). There is no apparent gender hierarchy; also, bodily differences did not have vital interplay in social relations. Although some social elements were regarded as masculine or feminine, sex-typing was not prevalent. Female roles were never hierarchically appreciated more than males and vice versa. Both genders recognized their different roles, and no superiority status was placed on one gender and gender-role over the other. Meanwhile, Adésuyì (2014) critiqued Oyewumi (2002) idea of an ungendered Yorùbá society; they do not recognize any popularity of gender hierarchy and sexism in Yorùbá culture. They cannot also claim that bodily forms define social relations as both genders is structured to complement the other in indigenous Yorùbá culture.

\section{Yorùbá Women and Colonialism: The Birth of Black Feminism}

On seeing gender hierarchy created as part of colonialism, Yorùbá women regrouped to question the problem. Hence, the popularity of the likes of Rabiatu Aláṣo Òkè, Madam Alimotu Péléwúrà, Chief Funmilayo Anikulapo-Kuti, Mrs. Oyinkan Abayomi, Mrs. H. Lawson, Mrs Ore Jones, Mrs Manuwa, Madam Idowu, etc. To explain how these women interpreted the relegation of their social status by British Europeans, they fought for redistribution of rights and recognition in this new system; perhaps, it is near impossible to defeat the system. Specific gender (female) anti-colonial activities would have been unnecessary if imported gender norms coalesced to customary gender norms. Consequently, Africa cultural interaction with the West birthed Black feminism and anti-colonial movements. This was before modern Western feminism became popular in the nineteenth century. Guy-sheftall (2003) buttressed that the struggle for women's rights in Africa is not a result and imitation of Eruo-American values nor effects of Western modernity.

The missionaries aimed to develop Yorùbá men to independently spread the gospel, thus, put men in charge of church affairs. In 1891, the first indigenous Yorùbá church was formed, with men as the authority. Because of later developments, a church was co-created by Abiodun Akinsowon (a female) around 1925. She refused the İyá İjo - Women leader of the church position, arguing on the presence of female prophetess in the Bible. Subsequently, her superior leadership was accepted by totality of church members. The same is the case for Madame 
Olatunrie, who also competed with a man by asserting that God had given her vision to form and lead a congregation (Oyěwùmí 1997). As female leadership is accepted in Yorùbá indigenous religion, the same was transferred to Christianity, and there is no sexual disparity in attendance, including present time.

As earlier described, missionary education in Western Nigeria assisted the creation of gender hierarchy. Ajala (1977) explained that missionary education was not primarily to develop souls for science and technology. Instead, it was to grow souls to read the Bible, create congregations and evangelism; therefore, men became the focal interest. Moreover, rivalry was apparent between the various missions (Church Missionary Society $\{\mathrm{CMS}\}$, Roman Catholic Missionary $\{\mathrm{RCM}\}$, American Baptist, and the Methodist $)$ in their efforts to preach and win the souls of the largest number of native population (Ajala 1977). However, questions should be asked on why the fourth oldest school in Nigeria - Methodist Girls High School, established in 1879 , was entirely a female school. The school history webpage reads that;

The aims of the founding fathers of the school were to give the girl-child, 'The highest literary training, of which they were capable and also to teach them domestic arts, such as cooking, sewing, mending, laundry, etc., and to become good wives and good mothers'. The school, therefore, aimed at giving the girls such an education that would enable them to contribute in a practical and meaningful way to the stability of family life within the society. (Methodist Girls' High School 2021)

Evidence shows that females were educated on the premise of becoming good wives and mothers and preparing the home comfortable for men to work. In later years, the colonial government also became interested in education. It became obvious that missionary education's primary purpose was Christianization. In contrast, the government, especially Lord Lugard, needed to create secretaries, clerks and administrators out of men to support the non-native colonialists (Mamdani 2001). Subsequently, the Kings college was created in 1909 to achieve modern education devoid of missionary activities. Similarly, it took 18 years and until 1927 to start a female colonial administered school - Queen's College, Lagos. Practically, it was only established as a result of the activities of Lagos elite women who raised some 1,000 pounds for the establishment of the school (Oyěwùmí 1997).

Western Nigerian women perceived the threat of colonialism to their interests and status, including social and economic organization (see Johnson, 1982). For example, it was the Lagos 
Women's League masterminded by Charlotte Olajumoke Obasa that fought for women's employment in the civil service (Oyěwùmí 1997; Johnson 1982; George 2007). George, in fact, sighted the problem of unwavering social immorality (prostitution, stealing, etc.) faced by young girls while carrying out economic and social empowerment activities on the streets of Lagos. Female bodies were underpaid, not appointed to senior cadres, and unlikely to control labour different from her type. These are connotations of Britain's colonialism enforced in Western Nigeria. Oyěwùmí (1997, p. 135) quoted a discriminatory circular during Nigeria’s colonial administration, noting that women should not be promoted to senior positions, except in extraordinary situations when the female-body is well qualified and would not control labour different from her own gender.

In social and political activism, Madam Alimotu Pelewura, Funmilayo Anikulapo Kuti etc., are fascinating. An author compared women's role in social organization and politics in Abẹòkúta, as a prominent location for active colonial and anti-colonial activities. 'The position of women in Abẹòkúta had deteriorated under the colonial order. In pre-colonial society women had participated in politics and had their own representatives, the most important of which was the İyálóde (sic), on state councils whose duty was to protect and promote women's interest' (Johnson 1982, 149).

Describing Chief Frances OluFunmilayo Ransome-Kuti, Johnson noted that the harrowing experience while schooling in Britain made her drop her first name to Funmilayo. She must have suffered varying intersectional discrimination as a Black woman. She, therefore, followed her sons' footsteps to replace Ransome with Anikulapo to became later known as Chief Funmilayo Anikulapo-Kuti. The chief and founder of the Abẹòkúta Ladies Club (an elite women group), felt the pains of market women and evolved the organization into Abẹòkúta Women's Union (AWU) to accommodate middle-class market women. Subsequently, they forced the Aláké of Ègbáland - King of Abẹòkúta to abdicate his throne due to colonial and anti-women activities. After this achievement, it became a national body with branches across Nigeria and a new nomenclature of Nigeria Women's Union (NWU).

Chief Funmilayo is an indigenous Yorùbá chief, i.e., İyálóde - Women Head. She was the only female representative in the 1947 London constitutional conference. Her appointment as part of the Nigeria Council of Nigeria and Cameroun (NCNC) political party delegates is not associated with 'gender equality' but with her charisma. There in London, she met with the 
Secretary of State for the Colonies and narrated specifically the pains of women. Probably, the discussion was favourable; hence, it gave her impetus for female activism to the extent of dethroning a revered Aláké of Ègbáland. The Aláké was fought because of anti-women activities, including excessive tax payment, forceful collection of market women goods for political reasons (food requisition), price controls, non-representation of women in Ègbá politics etc. The AWU was the first group to protest the king's removal. Later, the AWU gathered support, including from male-dominated organizations like the highly respected Ògbóni cult, until the Aláké temporarily abdicated the throne on January 3, 1949 (Johnson 1982; Johnson-Odim and Mba 1997). They also forced the inclusion of four women in the Sote Native Authority System, usually headed by the Aláké. This initial set-up refused to include females.

It is the same narrative with Madam Pelewura. She was outstanding with the Lagos Market Women Association (LMWA), who fought the colonial government in Lagos on market women's payment of tax. As a fishseller, she headed several markets and challenged the introduction of female taxation in Lagos (recall that tax had earlier been introduced in Abẹookúta and AWU only fought for its extortionary element). The LMWA successfully rejected the tax system first introduced in Lagos in 1932 and 1940 when a new Income Tax Ordinance followed. However, on December 18, 1940, Pelewura directly exchanged words with the colonial commissioner of Lagos, and the taxable income was subsequently increased from 50 to 200 pounds. Johnson (1982) described that few women could accrue that income. Yet, the limited success marked the official introduction of female taxation in Lagos.

Johnson had earlier narrated that the LMWA refused female tax because it is against Yorùbá customs and traditions. It is vital to note that there is no formal individual taxation in Yorùbá culture, except for communal taxation in the form of İsákộlẹ̣ and Owó Ilẹ. These were not paid individually but by the family, household, lineage or even a whole community. Colonial activities created personal income taxation, and females were exempted. Colonialism sees feminine body as a sub-being incapable of making enough income to pay tax, since they were disallowed employment to government works. However, on affirming the Yorùbá women's entrepreneurial nature and complementary breadwinner status, the colonial administrators' expanded the tax system to females. Also, in recognition of the need to pay tax, Johnson quoted the statement of Madam Alimotu from the Nigeria Archives in Ibadan (NAI) - the scar of wartime hardship was significant on Lagos women; the women had to feed their unemployed 
husbands \& relatives and assist them in tax payments to protect them from arrest and imprisonment. The women demanded that women would not pay tax, unless there is female franchise (Johnson 1982).

This statement depicted that the women desired representation in politics and political processes, especially if they would be made to pay tax. Also, it showed the complementary family role played by women in paying the taxes of their husbands or even being the breadwinners of the family in some cases (Akanle, Adesina, and Nwaobiala 2018). Women worked during this period in agriculture, trading, and distribution to contribute income to the family. It is not Yorùbá-like that a woman/wive should sit at home and wait for daily bread, despite men's recognition as family head. They even work in the same industry as men until today (Akanle, Adesina, and Nwaobiala 2018). Akanle et al. (2018) also related the implications of female breadwinners in family settings; however, these implications can be argued as consequences of interaction with Western colonialism, neo-colonialism, and globalization. Women have been traditionally known to be home supporters, and their husbands did not seek to usurp this position.

Conclusively, colonialism creation of gender hierarchy is also apparent in the history of political representation in Nigeria. Women were disallowed to vote (Adetunji 2013) and forbidden representation in native authorities, government councils and committees. The fight for voting rights, girls' education and literacy, female employment in civil service, protection of market women formed the core function of the Nigerian Women's Party (NWP) headed by Oyinkan Abayomi (George 2007). The NWP commanded the status of the first female-led party when female franchise was granted in 1950. It was after some years that Chief Funmilayo also formed the Commoners People Party (Johnson-Odim and Mba 1997)

\section{Women Roles in Yorùbá Society}

In the Yorùbá culture, the place of women is invaluable. Through arts, literature, drama, and songs, women are regarded as jewels, and their positions in society are indispensable. Women occupy roles like daughter, wife, sister, mother, and even a witch (Makinde 2004). Social expectations put females to be relatively available to reciprocate care to their parents at old age and are source of pride when they get married; thus, they are dignified and respected. A female daughter in Yorùbá South-Western Nigeria could bring wealth and prestige to the family when they get married (Makinde 2004). 
In the traditional Yorùbá language, a wife is called İyàwó and the first wife (polygyny is popular) İyá Ilé - Female House Leader. Childbirth usually cements womens' place in their husbands' families, including if a divorce occurs. A child is revered enormously in Yorùbá culture, and a wife who cannot bear children would be pressured by the husband or in-laws. According to Makinde (2004), giving birth to a child confers on the mother power to exercise authority in the husband's home. Thus, a wife who gives birth in her husband's home becomes a precious stone and an irreplaceable stakeholder to her in-laws, her own family, and community. Motherhood is the highest honour every woman is offered in Yorùbá culture. A female divorcee who has given birth in a family is allowed access to the child, the husband, and in-laws. Meanwhile, accounts of females not giving birth are not popular in Yorùbá culture, as powerful female deities like Ọșun are consulted. However, in the rare case that efforts prove abortive, this would usually place a scar on their status.

A mother also receives admiration whenever she bears a child that attains marriage. In fact, in the Yorùbá marriage system, aside from the specific groom and bride, the İyá İyàwó - Mother of the Bride is the next person to check out. She is believed to have made buoyant investments to graduate a woman under her care to another family; thus, the İyá Ìyàwó is distinctly celebrated. The İyá İyàwó is also severely respected by the groom upon the consummation of the marriage. Also, a female daughter is a sister-in-law and has authority over fellow female folks (older or otherwise) married to her parental families. A wedded wife must not call her sister-in-law by name; she must honour, respect, and put titles to their names. Women priceless roles show how much they are respected, until today, in the Yorùbá cultural system.

\section{Conclusion and Recommendations}

A Yorùbá woman is a source of marked status that depicts respect, privilege, esteem, and envy. Akanle et al. (2018) asserted that Yorùbá women are not socialized to perform family breadwinning functions, instead, they complement their husbands who is the lead breadwinner. The Yorùbá culture marked the duo genders with different but similar roles and responsibilities. A female complements a male, not subordinate nor subjugated to him. Women held clear cut enviable positions, unlike those that currently belittle them in the face of colonial interaction. The man is the head, while the woman is the deputy and not a servant. These can be seen in many Yorùbá spoken words/proverbs that Ọkọ Lolówó Orí Aya - The husband is the head of

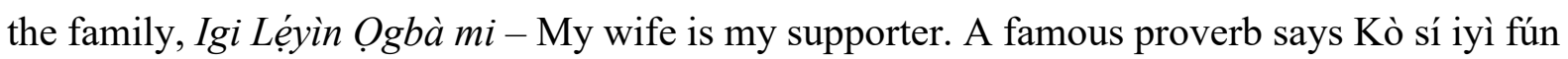


ọba tí kò ní olorì- no pride for a king without a queen. This points to the heterosexual norm in Yorùbá culture. Yorùbá people usually frown at promoting unmarried men to authority positions, like becoming a king. This does not provide a sexual material or a punching bag for men; instead, it seeks to provide someone to advise and revise the king's policies. There must be a queen for every Yorùbá king, and for every adult, there must be a wife(ves). Femininity is a revered institution in Yorùbá land.

Pan-African feminism and Black feminism have explained that mainstream feminism does not recognize Africa females rights and status as displayed in the rich traditional African culture (Wane 2011). Oyěwùmí (1997) described that intertwined processes of European colonization made Black women invisible as they occupied a fourth invisible order in the hierarchy of colonial bodies. The first structure placed colonial settlers above natives (Mamdani 2001), and then inferiorization of the female gender. 'In the colonial situation, there was a hierarchy of four, not two, categories. Beginning at the top, these were: men (European), women (European), native (African men), and Other (African women). Native women occupied the residual and unspecified category of the Other' (Oyěwùmí 1997, 122).

Yorùbá pre-colonial society was a gender-neutral, gender-fluid, and gender-silence society. Women played complementary and not competitive roles to men. However, this complementariness cannot be deleted or replaced by a man. Adetunji (2013, p. 25) put it outrightly in a study on women's role in socio-religious Yoruba context that 'gender differences does not suggest oppression and domination of one over the other as the case may be in some cultures but a complementary relationship'. They further explained that complementary is qualified with neutrality 'to refer not to equality or parity but to cooperation and specified areas of control for the female as well as the male'. Consequently, it is critical to caution and rethink current Yorùbá society feminist activities. Two questions must be asked henceforth - are feminist activities required? And what approach should feminism take in Yorùbá culture? Obviously, there is vital need for more recognition and redistribution (Fraser 1998) and 'controlled' female representation in business, politics, education, law, etc. This 'need' must identify with the constructed status of women in Yorùbá culture.

Feminism (scholarship and activities) in Yorùbá society must understand the varied gender context of Africa to Euro-America culture. Western feminism is premised on marked gender hierarchy and binary; ours is the opposite. Subsequently, feminist activities should aim to 
improve the recognition of women as constructed in Yorùbá tradition. As such, the point of departure for feminist movements must recognize women's activities on anti-colonial oppression. In doing that, feminists must appreciate women's indigenous status before the arrival of settlers and aspire to build on that status. Yorùbá culture heteronormativity must be distanced from Western sexism, which influenced Western feminism.

A national education rich in uncontaminated culture and traditions must be recommended in advising Yorùbá people on the extent and amount of feminist action. Oyěwùmí (1997) challenged that the greatest harm of colonialism is the misplacement of Africa history. Western philosophy is further taken as universalism as it continually influences thought and education systems (Oyewumi 2002). Research must deconstruct and reconstruct Africa history (Le Grange 2016) so that the population can identify and improve Yorùbá cultural recognition of females. Students would become alien to their culture and overzealous in correcting gender inequality inherent in Eurocentric education vis-à-vis Western feminism. Also, present feminist activities should be premised on a 'shared text of blackness' (Mangcu 2016). Their actions should identify with Africa and seek recognition and redistribution based on Africa's construction of gender.

\section{References}

Aderinto, Adeyinka. 2001. "Subordinated by Culture: Constraints of Women in a Rural Yoruba Community, Nigeria.” Nordic Journal of African Studies 10 (2): 176-87. Adésuyì, Olúkáyòdé R. 2014. "Is There a Place That Is Non-Gendered in This World?: A Critique of Oyewumi’s Non Gendered Yorùbá Family.” Rupkatha Journal on Interdisciplinary Studies in Humanities 6 (2): 23-33.

Adetunji, Adelowo Felix. 2013. "Women as Vocalists in Sango Cult of Yoruba Indiginous Religion: An Analogy for the Roles of Modern Women in Nigerian Politics and National Development." Kuwait Chapter of Arabian Journal of Business and Management Review 2 (7): 10-26. doi:10.12816/0001214.

Ajala, Oyewole O. 1977. "A Historical Review of Secondary Education in Western Nigeria: 1842-1976." North Texas State University.

Akanle, Olayinka, Jimi O. Adesina, and Uzoamaka R. Nwaobiala. 2018. "Turbulent but I Must Endure in Silence: Female Breadwinners and Survival in Southwestern Nigeria." Journal of Asian and African Studies 53 (1): 98-114. doi:10.1177/0021909616658913. Amadiume, Ifi. 1987. Male Daughters, Female Husbands: Gender and Sex in an African 
Society. London: Zed Books.

Creevey, Lucy E. 2000. "Review of the Invention of Women: Making an African Sense of

Western Gender Discourses by Oyèrónké Oyěwùmí." The Journal of Modern African

Studies 38 (2): 341-42.

Fanon, Frantz. 1961. The Wretched of the Earth. Middlesex: Penguin Books.

Ficek, Douglas. 2011. “On Familial and Socio-Political Possibilities.” Philosophy and Social Criticism 37 (8): 947-54. doi:10.1177/0191453711413719.

Fraser, Nancy. 1998. "Social Justice in the Age of Identity Politics: Redistribution,

Recognition, and Participation.” Berlin: Wissenschaftszentrum Berlin für

Sozialforschung. doi:10.4135/9781446218112.n2.

George, Abosede A. 2007. "Feminist Activism and Class Politics: The Example of the Lagos

Girl Wawker Project." Women's Studies Quarterly 35 (3/4): 128-43.

https://www.jstor.org/stable/27649700?seq=3\#metadata_info_tab_contents.

Grange, Lesley Le. 2016. "Decolonising the University Curriculum." South African Journal of Higher Education 30 (2): 1-12. doi:10.4324/9781351061629-14.

Guy-sheftall, Beverly. 2003. "African Feminist Discourse: A Review Essay.” African

Feminist Discourse 17 (58): 31-36.

Henslin, James. 2010. Sociology A Down-To-Earth Approach. 10th Ed. Pearson.

Imam, Hauwa. 2012. "Educational Policy in Nigeria from the Colonial Era to the Post-

Independence Period.” Italian Journal of Sociology of Education 4 (1): 181-204.

Johnson-Odim, C, and N. Mba. 1997. For Women and the Nation: Funmilayo Ransome-Kuti

of Nigeria. University of Illinois.

Johnson, Cheryl. 1982. "Grass Roots Organizing: Women in Anticolonial Activity in

Southwestern Nigeria." African Studies Review 25 (2): 137-57.

Kaya, Hassan O., and Yonah N. Seleti. 2014. “African Indigenous Knowledge Systems and

Relevance of Higher Education in South Africa." International Education Journal:

Comparative Perspectives 12 (1): 30-44.

King, Adele. 1998. "Review of the Invention of Women: Making an African Sense of

Western Gender Discourses by Oyèrónké Oyěwùmí." World Literature Today 72 (4):

880.

Kuykendall, Ronald. 2016. "Hegel and Africa : An Evaluation of the Treatment of Africa in the Philosophy of History" 23 (4): 571-81.

Lugones, Maria. 2008. "The Coloniality of Gender." Worlds \& Knowledges Otherwise, 1-10.

Makinde, Taiwo. 2004. "Motherhood as a Source of Empowerment of Women." Nordic 
Journal of African Studies 13 (2): 164-74.

Mamdani, Mahmood. 1996. Citizen and Subject: Contemporary Africa and the Legacy of

Late Colonialism. New Jersey \& West Sussex: Princeton University Press.

_.2001. "Beyond Settler and Native as Political Identities: Overcoming the Political

Legacy of Colonialism." Comparative Studies in Society and History 43 (4): 651-64. doi:10.1017/S0010417501004285.

Mangcu, Xolela. 2016. "Decolonizing South African Sociology: Building on a Shared 'Text of Blackness."” Du Bois Review 13 (1): 45-59. doi:10.1017/S1742058X16000072.

Manicom, Desiree. 2001. "Review of the Invention of Women: Making an African Sense of Western Gender Discourses by Oyèrónké Oyěwùmí.” Agenda: Empowering Women for Gender Equity, no. 50: 132-35.

Martin, Emily. 1991. "The Egg and the Sperm: How Science Has Constructed a Romance Based on Stereotypical Male-Female Roles." Journal of Women in Culture and Society $16(3): 485-501$.

Methodist Girls' High School. 2021. “A Brief History of MGHS.” School Website. Accessed June 18. https://mghsyabalagosng.com/history-2/.

Ọpẹfèyítìmí, Ayọ̀. 2014. Tiónrì Àti İsọoọlo-Èdè. Last ed. Ilé ifẹ̣: Ọbáfệmi Awólộọ̣ University Press.

Oyewumi, Oyeronke. 2002. "Conceptualizing Gender: The Eurocentric Foundations of Feminist Concepts and the Challege of African Epistemologies.” Jenda, no. 3.

Oyěwùmí, Oyèrónkẹ. 1997. The Invention of Women: Making an African Sense of Western

Gender Discourse. Minneapolis, London: University of Minnesota Press.

- 2016. What Gender Is Motherhood? Changing Yorùbá Ideals on Power,

Procreation, and Identity in the Age of Modernity. Gender and. New York, USA:

Palgrave Macmillan. doi:10.1057/9781137521255.

Pogoson, A Irene. 2012. "Gender, Political Parties and the Reproduction of Patriarchy in

Nigeria: A Reflection on the Democratisation Process, 1999-2011.” Journal of African

Elections 11 (1): 100-122. doi:10.20940/jae/2012/v11i1a6.

Rodney, Walter. 1972. How Europe Underdeveloped Africa. 2009 ed. Abuja: Panaf

Publishing, Inc. doi:10.2307/484037.

Wane, Njoki. 2011. “African Indigenous Feminist Thought; an Anti-Colonial Project.” In The Politics of Cultural Knowledge, edited by Njoki Wane, Arlo Kempf, and Marlon Simmons, 7-21. Sense publishers. 


\section{Disclosure Statement}

The authors declare that there are no financial or non-financial competing interests to report.

\section{Acknowledgement}

This report has been presented to the faculty staff of the Department of Sociology, UNILAG and the South African Sociological Association (SASA) 2021 conference. We appreciate their contributions. 